\title{
Strategic Positioning, Monetary Policy and Capital Structure
}

\author{
Zhu Bao ${ }^{* 1}$, Ma Zhong ${ }^{1}$, Wang Longfeng ${ }^{1}$ \\ 1. School of economics and management, Beijing Jiaotong University \\ Zhu Bao Email: 362052108@qq.com
}

\begin{abstract}
Taking Shanghai and Shenzhen A-share non-financial listed companies from 2009 to 2018 as samples, the paper empirically examines the impact of strategic positioning on capital structure decision-making. The results show that firms with more radical strategies are more likely to choose higher capital structure, and the conclusions are still robust after the endogenous problems are alleviated by regression of instrumental variables; under loose monetary policy, the impact is more significant; after distinguishing between state-owned enterprises and private enterprises, the study finds that in the sample of state-owned enterprises, the higher leverage decision-making of the firms with more radical strategies is more significant.
\end{abstract}

Keywords: strategy, monetary policy, capital structure

\section{INTRODUCTION}

As a decisive factor affecting the company's operation and decision-making, corporate strategy directly affects the development goals, profit models and organizational structure of enterprises (Miles and Now, 1978) [1]. Strategic management research shows that enterprises can improve the efficiency and efficiency of production and operation, enhance their own value and achieve specific competitive advantages by implementing growth-oriented strategy, but it may also lead to excessive expansion of enterprises, or even business failure. However, as an important micro entity to promote the transformation and upgrading of China's economy, the strategy of listed companies has not been widely valued in domestic accounting and financial research.

At present, although the research in the field of corporate finance pays attention to the influencing factors and economic consequences of capital structure decisionmaking, there are relatively few studies on corporate strategy and capital structure decision-making. What impact does corporate strategy have on capital structure decision-making? How does a company with radical strategy make capital structure decision under different monetary policies? The paper uses the sample of A-share non-financial listed companies in Shanghai and Shenzhen from 2009 to 2018 to explore the impact of corporate strategic characteristics on capital structure decisionmaking, and examines the impact of corporate strategy on capital structure decision-making under different monetary policies.

\section{THEORETICAL ANALYSIS AND RESEARCH HYPOTHESIS}

Strategy is the overall, long-term and stable decisionmaking and action of an enterprise. Corporate strategy has a far-reaching impact on financial decision-making. Companies that adopt aggressive strategies maintain a leading position in the industry by continuously developing new products and expanding new markets. Defensive strategic companies maintain competitiveness by lowering prices and improving the quality of products and services. Analytical strategy is a strategic type between offensive and defensive. Enhancing communication between insiders and outsiders, improving corporate performance, reducing transaction costs, and more easily gaining investors' attention, so as to have the conditions to maintain high leverage. Overconservative strategic decision-making may also lead to excessive internal human rights, exacerbating management trenches and agency costs. According to the principal-agent theory, there is a phenomenon of inconsistency of interests between insiders and investors, such as enterprise management, etc. Management often sacrifices the interests of investors such as shareholders to enhance their private benefits. Higher agency costs aggravate the problem of information asymmetry, the more likely it is to lead to higher transaction costs of 
financing, and higher debt financing costs lead to lower capital structure, while radical. Corporate strategy may broaden the source of corporate debt resources by alleviating the degree of information asymmetry and reducing the cost of debt financing. Accordingly, hypothesis 1 is proposed in the paper.

H1: The higher the degree of strategic radicalization, the higher the leverage of enterprises.

According to the theory of preferred-order financing, when monetary policy is loose, enterprises' profit expectation increases. According to the order of endogenous financing-debt financing-equity financing, enterprises tend to increase investment opportunities, and enterprises tend to increase liabilities. When monetary policy is tight, enterprises' profit expectation decreases and investment opportunities decrease, which tends to reduce debt financing. The impact of strategic radicalization on capital structure decision-making may be regulated by monetary policy, that is, the looser the monetary policy, the greater the impact of strategic radicalization on corporate leverage. Accordingly, hypothesis 2 is proposed in the paper.

$\mathrm{H} 2$ : Monetary policy positively regulates the impact of strategic intensity on corporate leverage.

\section{RESEARCH DESIGN}

\subsection{Samples and Data}

The paper takes all listed companies of A-share motherboard, SME board and GEM from 2009 to 2018 as initial samples, and screens them according to the following criteria: (1) Because most variables in the model need to use the financial data and market transaction data of the previous year, the samples just listed in that year are excluded; (2) companies with incomplete data and delisting are excluded; (3) companies with incomplete data are excluded from the listing of financial and insurance industry. Company. In order to avoid the interference of extreme values, all continuous variables were processed by WINSOR with $1 \%$ and $99 \%$ scales. The final sample involved the annual observations of 10700 listed companies. The financial data of listed companies are from Wind and CRSMAR databases.

\subsection{Variable Definition}

Capital structure (Lev). As the paper focuses on the impact of strategic positioning on the decision-making of enterprise capital structure, we use the asset-liability ratio as the proxy variable to measure enterprise capital structure, referring to Blaylock et al. (2017) [2]. Strategic positioning is measured by STRA. Use existing research (Bentley et al., 2010) for reference to select indicators to identify strategic positioning [3]. Referring to Bentley's research, the paper takes the average of the six variables in the past five years. The higher the STAR is, the more radical the company's strategy is. On the contrary, the more conservative it is.Monetary policy (M2). The paper refers to Meng Wei et al. (2018) to measure the growth rate of M2 as a measure of monetary policy. The larger the index, the looser the monetary policy[4]. Drawing on the research of Wang Jin and Guo Kun (2019) [5], the paper chooses enterprise scale ( Size), enterprise profitability (PB), enterprise growth (ROE), Equity concentration (Concen), Board size (Direct), The proportion of independent directors (IndDIR), year and industry as control variables.

\subsection{Research Model}

Based on the above theoretical analysis and the study of Opler et al. (1999) [6], model 1 is established to verify the impact of corporate strategy on capital structure decision-making. If the coefficient of STRA is significantly positive, it shows that the more radical the company strategy, the higher the enterprise leverage. The model controls the factors affecting cash holdings, such as the size of the contracting enterprise, the profitability of the enterprise, the growth of the enterprise, the factors of corporate governance, the year and the industry.

$$
\begin{aligned}
& \operatorname{Lev}_{\mathrm{i}, \mathrm{t}}=a_{0}++a_{1} \text { STRA }_{\mathrm{i}, \mathrm{t}}+\sum_{i=1}^{n} a_{i} \text { CONTROLS } \\
& + \text { YEAR }+ \text { INDUSTRY }+e
\end{aligned}
$$

In order to test the moderating effect of monetary policy on capital structure decision-making, model 2 is established. If the multiplier M2* STRA is significantly positive, it shows that loose monetary policy increases the high bar effect of radical strategy, that is, aggressive companies obtain development resources through borrowing under the loose monetary policy environment.

$$
\begin{aligned}
& \operatorname{Lev}_{\mathrm{i}, \mathrm{t}}=a_{0}++_{1} \text { STRA }_{\mathrm{i}, \mathrm{t}}+a 2 M_{2}+a_{3} \operatorname{STRA}^{*} M 2+\sum_{i=1}^{n} a_{i} \text { CONTROLS }_{\mathrm{i}, \mathrm{t}} \\
& + \text { YEAR }+ \text { INDUSTRY }+e
\end{aligned}
$$

\section{EMPIRICAL RESULTS}

\subsection{Descriptive Statistics}

Table 1 is the descriptive statistics of the main variables. From Table 2, we can see that the average asset-liability ratio of listed companies is 0.492 , the minimum is 0.007 , and the maximum is 0.987 . There are significant differences in capital structure decisions 
between companies. The index of corporate strategic radical process is 11.38 , and the average growth rate of money quantity is 0.132 .

Table 1 Descriptive statistics

\begin{tabular}{ccccccccc}
\hline variable & $\mathrm{N}$ & mean & $\mathrm{sd}$ & $\mathrm{min}$ & $\mathrm{p} 25$ & $\mathrm{p} 50$ & $\mathrm{p} 75$ & $\max$ \\
\hline Lev & 10700 & 0.492 & 0.198 & 0.00710 & 0.344 & 0.499 & 0.643 & 0.987 \\
STRA & 10700 & 11.38 & 4.069 & 2 & 8 & 11 & 14 & 21 \\
Size & 10700 & 22.52 & 1.337 & 17.76 & 21.65 & 22.40 & 23.31 & 28.52 \\
PB & 10700 & 3.905 & 11.41 & 0.121 & 1.592 & 2.485 & 3.997 & 520.1 \\
ROE & 10700 & 0.115 & 1.990 & 0.000100 & 0.0358 & 0.0725 & 0.122 & 204.7 \\
M2 & 10700 & 0.132 & 0.0504 & 0.0810 & 0.0820 & 0.133 & 0.136 & 0.277 \\
Concen & 10700 & 34.90 & 15.36 & 0.286 & 22.77 & 32.79 & 45.44 & 89.09 \\
Direct & 10700 & 8.950 & 1.827 & 3 & 8 & 9 & 9 & 18 \\
IndDIR & 10700 & 0.371 & 0.0559 & 0 & 0.333 & 0.333 & 0.400 & 0.800 \\
\hline
\end{tabular}

\subsection{Empirical Regression Results}

Multivariate regression results of model (1) are shown in columns (1) and (2) of table 4. In order to control the interference of individual factors and time factors, columns (1) and (2) adopt fixed effect regression, while controlling year and industry variables. Columns (1) are not included in the main control variables and columns (2) are included in the main control variables. From the results of two columns (1) (2) in Table 2, we can see that the regression coefficients of corporate strategy (STRA) are 0.004 and 0.002 , which are significantly positive at the level of $1 \%$, indicating that the more radical the corporate strategy is, the higher the asset-liability ratio is. The hypothesis $\mathrm{H} 1$ in the paper has been verified.

The multiple regression results of model (2) are shown in column (3) of table 4. From the results of column (3) of table 2, the regression coefficients of STRA* M2 are 0.0111 , which is significantly positive at $1 \%$, indicating that the looser the monetary policy is, the higher the corporate leverage under the radical corporate strategy is. Suppose H2 is verified.

Table 2 Benchmark test results

\begin{tabular}{|c|c|c|c|}
\hline & (1) & (2) & (3) \\
\hline & Lev & Lev & Lev \\
\hline \multirow[t]{2}{*}{ STRA } & $0.0043^{* \star *}$ & $0.0017^{\star \star *}$ & 0.0001 \\
\hline & (8.3590) & (3.1585) & $(0.0776)$ \\
\hline \multirow[t]{2}{*}{$\mathrm{M} 2$} & & & $0.3393^{* * *}$ \\
\hline & & & $(4.2166)$ \\
\hline \multirow[t]{2}{*}{ STRA* M2 } & & & $0.0111^{\star *}$ \\
\hline & & & (2.0779) \\
\hline \multirow[t]{2}{*}{ PB } & & $0.0022^{* * *}$ & $0.0022^{* * *}$ \\
\hline & & (18.5149) & (18.5240) \\
\hline \multirow[t]{2}{*}{ ROE } & & 0.0005 & 0.0005 \\
\hline & & (0.9982) & $(1.0022)$ \\
\hline \multirow[t]{2}{*}{ Concen } & & 0.0000 & 0.0000 \\
\hline & & (0.1293) & $(0.1118)$ \\
\hline \multirow[t]{2}{*}{ Size } & & $0.0602^{* * *}$ & $0.0611^{\star * *}$ \\
\hline & & (21.8709) & (21.9298) \\
\hline
\end{tabular}




\begin{tabular}{|c|c|c|c|}
\hline \multirow[t]{2}{*}{ SOE } & & $0.0231^{* * *}$ & $0.0226^{* \star *}$ \\
\hline & & $(2.9641)$ & (2.8890) \\
\hline \multirow[t]{2}{*}{ Direct } & & $-0.0026^{* *}$ & $-0.0025^{* *}$ \\
\hline & & $(-2.0419)$ & $(-1.9633)$ \\
\hline \multirow[t]{2}{*}{ IndDIR } & & -0.0239 & -0.0228 \\
\hline & & $(-0.7601)$ & $(-0.7237)$ \\
\hline YEAR & YES & YES & YES \\
\hline INDUSTRY & YES & YES & YES \\
\hline \multirow[t]{2}{*}{ _cons } & $0.4403^{* * \star}$ & $-0.8468^{* * \star}$ & $-0.9789^{* \star *}$ \\
\hline & (11.2279) & $(-11.8565)$ & $(-12.9020)$ \\
\hline$N$ & 10693 & 9269 & 9269 \\
\hline$R^{2}$ & 0.0460 & 0.1270 & 0.1275 \\
\hline
\end{tabular}

\section{EXPANSION TEST AND ROBUSTNESS TEST}

\subsection{Expansion Test}

There are significant differences between the financing environment of state-owned enterprises and private enterprises. In order to further explore the impact of strategic positioning of state-owned enterprises and private enterprises on capital structure decision-making, the paper studies the regulatory role of property rights through grouping tests. it can be seen that the regression coefficient of the strategic radical degree of state-owned enterprise group is significantly positive at the level of $1 \%$, while the regression coefficient of the strategic radical degree of private enterprise group is not significant. In state-owned enterprises, the high leverage effect of strategic radical process is more obvious. ${ }^{\text {(1) }}$

\subsection{Robustness Test}

In order to alleviate the impact of endogenous problems on the conclusions, the paper uses the instrumental variable method to alleviate endogenous problems, the paper chooses the first-order lag item (l. STR) of strategic positioning as the instrumental variable, and uses 2SLS as the instrumental variable to regression alleviate the endogenous problem.

The F value of the first stage is 1573.72 , which is far greater than 10, indicating that the instrumental variables satisfy the relevant conditions. The regression coefficient of company strategy (STRA) is 0.002, which is significantly positive at the $1 \%$ level, indicating that the results of the paper are robust. ${ }^{1}$

\section{CONCLUSION}

The paper empirically tests the impact of strategic positioning on corporate leverage. The results show that firms with more radical strategies are more likely to face higher capital structure. Enterprises will increase loans and leverage to expand the access to financial resources for development. Loose monetary policy provides conditions for enterprises to obtain debt resources, and this effect is more significant under loose monetary policy.

\section{REFERENCES}

[1] Miles R E, Snow C. Organizational Strategy, Structure and Process [M]. New York: Mc GrawHill, 1978.

[2] Blaylock B, Gaertner F B, Shevlin T. Book-tax conformity and capital structure $[\mathrm{J}]$. Review of Accounting Research, 201722 (2): 903-932.

[3] Bentley K A, Omer T C, Sharp N Y. Business strategy, financial reporting irregularities, and audit effort [J]. Contemporary Accounting Research, 2013, 30 (2): 780-817.

[4] Meng W, Guo X. Monetary policy, liquidity management and enterprise value creation, [J]. Collected Essays on Finance and Economics, 2018 (08): 55-64. (in Chinese)

[5] Wang J, Guo K. Research on the impact of tax avoidance on capital structure of listed companies [J]. Finance and Trade Research, 2019, 30 (05): 99110. 65 (in Chinese)

[6] Opler T, Pinkowitz L, Stulz R, et al. The determinants and implications of corporate cash holdings [J]. Journal of Financial Economics, 1999, 52 (1): 3-46. 